Article

\title{
Are Cutbacks to Personal Assistance Violating Sweden's Obligations under the UN Convention on the Rights of Persons with Disabilities?
}

\author{
Ciara Brennan ${ }^{1, *}$, Rannveig Traustadóttir ${ }^{1}$, Peter Anderberg ${ }^{2}$ and James Rice ${ }^{1,3}$ \\ 1 Centre for Disability Studies, Faculty of Social and Human Sciences, University of Iceland, Sturlugata, \\ 101 Reykjavík, Iceland; rannvt@hi.is (R.T.); james@hi.is (J.R.) \\ 2 Department of Health, Blekinge Institute of Technology, SE-371 79 Karlskrona, Sweden; \\ peter.anderberg@bth.se \\ 3 Department of Anthropology, University of Iceland, Oddi 332, Sæmundargötu 2, 101 Reykjavík, Iceland \\ * Correspondence: csb1@hi.is; Tel.: +354-526-4523
}

Academic Editor: Anna Arstein-Kerslake

Received: 17 February 2016; Accepted: 5 May 2016; Published: 16 May 2016

\begin{abstract}
Article 19 of the UN Convention on the Rights of Persons with Disabilities requires states to ensure that disabled people can choose where and with whom they live with access to a range of services including personal assistance. Based on qualitative research of the implementation of Article 19 in Nordic countries, this paper focuses on Sweden, which was at the forefront of implementing personal assistance law and policy and has been the inspiration for many European countries. Instead of strengthening access to personal assistance, this study found that since the Swedish government ratified the Convention in 2008, there has been an increase in the numbers of people losing state-funded personal assistance and an increase in rejected applications. This paper examines the reasons for the deterioration of eligibility criteria for accessing personal assistance in Sweden. The findings shed light on how legal and administrative interpretations of "basic needs" are shifting from a social to a medical understanding. They also highlight a shift from collaborative policy making towards conflict, where courts have become the battleground for defining eligibility criteria. Drawing on the findings, we ask if Sweden is violating its obligations under the Convention.
\end{abstract}

Keywords: independent living; personal assistance; Sweden; the United Nations Convention on the Rights of Persons with Disabilities

\section{Introduction}

The United Nations Convention on the Rights of Persons with Disabilities ${ }^{1}$ opened for signatures in March 2007 and entered into force in May 2008. The Convention "embodies a 'paradigm shift', from the charitable and the medical approaches to disability to one which is firmly rooted in human rights" [1]. Article 19, in particular, "expresses the paradigm shift by outlining a series of tangible obligations to achieve independent living (something assumed for most people) and inclusion in the community" ([2], p. 22). Under the heading "Living independently and being included in the community" it requires states to ensure that "persons with disabilities have access to a range of in-home, residential and other community support services including personal assistance necessary to support living and inclusion in the community". The paradigm shift also requires the involvement of disabled people's organizations (DPOs) [3]. To comply with Articles 33.3 and 4.3, states need to involve

1 Hereafter referred to as the CRPD or the Convention. 
organizations representing disabled people when bringing law and policy in line with the obligations in Article 19-“"some of which have immediate effect and others which are subject to "progressive achievement" over time" ([2], p. 24). Yet, "even where progressive achievement is the case, states are under an obligation to show that they are taking steps to the maximum of their available resources to implement this right" ([4], p. 31). Contrary to this, regressive measures are ones "that directly or indirectly leads to backwards steps being taken" with regard to obligations under international law ([5], p. 28).

The Convention aims to strengthen access to support services, including personal assistance in all state parties that ratify the CRPD including countries that already have such policies in place. Contrary to this, Sweden, which is often regarded as the "golden standard" of personal assistance law and policy in Europe [6], has in recent years, narrowed eligibility for personal assistance and has seen a sharp increase in the numbers of people losing state-funded personal assistance. In 2007, the year the Swedish government signed the Convention, 56 persons had their state-funded personal assistance removed [7]. This number increased significantly in the following years. The number of persons who lost their personal assistance peaked in 2012, when 284 people lost their assistance. The latest figures from 2015 show that 145 lost state funded personal assistance [7]. Furthermore, the proportion of first time applicants being denied personal assistance has increased. In 2007, the same year that the Sweden signed the Convention, $34.5 \%$ of applications were rejected. The latest figures from 2015 show that rejected applications have risen to $68.8 \%$ [7].

This paper examines why and how these cutbacks have occurred following the ratification of a UN Convention that requires access to personal assistance services and should strengthen the right to live independently in the community. The paper is based on a qualitative research project carried out between 2011 and 2014, which examined the implementation of Article 19 of the Convention in Iceland, Norway and Sweden [8,9]. The qualitative project involved in-depth semi-structured interviews with leaders of the independent living movement and government officials who oversee the implementation of the policy changes in Sweden. The findings of the qualitative fieldwork lead us to undertake an extensive review of laws, policies and literature on personal assistance in Sweden. This paper focuses on the findings of this extensive review and aims to shed light on the deterioration of personal assistance policy and discuss it in relation to Sweden's obligations under the CRPD. Section 2 describes the methods used in the study. Section 3 outlines the development of the international independent living movement and personal assistance, and their connection to the CRPD principles. Section 4 introduces Swedish personal assistance law and policy, examines the government's justifications for the review of this law and describes the changes that have occurred in recent years as a result of court rulings and the bureaucratic reinterpretation of "basic needs" and eligibility criteria. In Section 5, we discuss the changes to Swedish personal assistance law and policy and conclude by asking if Sweden is violating its commitments under the Convention.

\section{Methods}

This is one in a series of articles written as part of a larger project that aimed to examine the development and the implementation of Article 19 of the CRPD, with a focus on the Nordic countries. The overall objective of the project was to chart progress towards independent living and personal assistance. We aimed to provide an in-depth and critical understanding of the meaning of independent living and personal assistance. Qualitative research was conducted in Iceland, Norway and Sweden. Of these three countries Sweden was of particular interest because it is commonly considered to have the most advanced and extensive personal assistance law and policy in Europe [6]. In this article, we focus on Sweden where the qualitative research comprised two stages: fieldwork and an in-depth review of policy, law and literature on Swedish personal assistance. This paper focuses on the latter stage of the research. The review of Swedish law, policy and literature was informed by qualitative fieldwork that carried out in Sweden between January and May 2013. In-depth, semi-structured interviews were carried out with 19 leading figures in the Swedish independent living movement. 
Follow-up interviews were conducted with four policy makers and government officials who were responsible for reviewing and implementing changes to Swedish personal assistance policy. Fieldwork was carried out by the first author of this paper.

The constant comparative method of grounded theory was used to collect and analyze the qualitative data [10]. This involves analyzing the data, creating analytical memos during the data collection process and searching for central themes "and to continue looking (and interviewing) until the new information obtained does not further provide insight" [11]. We began with a broad set of questions about personal assistance and Article 19, but these became more focused as themes began to emerge. For example, analysis of interviews in Sweden indicated that many participants who were entitled to personal assistance feared that they would lose hours or their personal assistance would be removed altogether. Furthermore, government officials were in the process of reviewing and implementing new measures that narrowed the eligibility criteria for personal assistance. The findings of the qualitative fieldwork lead us to undertake an in-depth review of law, policy and literature on personal assistance in Sweden. All public policy papers since the ratification of the CRPD were reviewed as part of this stage of the research. This included a major policy paper, which analyzed court cases and interpreted the rulings to define "basic needs" for personal assistance [12]. There court cases have directly affected the assessment process for determining if and to what extent an individual is entitled to personal assistance. We examined these policy reviews and court cases in relation to the human rights commitments made by the Swedish government when it ratified the CRPD. Furthermore, we analyzed documents about the development and the history of independent living and personal assistance in Sweden. The findings of this review are outlined and discussed in this paper.

\section{The Independent Living Movement and the UN Convention on the Rights of Persons with Disabilities}

Personal assistance is rooted in disability rights activism. It began as a political struggle, which was initiated by a group of disabled students on the campus of the University of California, Berkeley in the late 1960s [13]. Independent living principles promote user-led services that enhance participation in society and equality with other citizens. Independence does not mean doing everything by oneself or living in isolation from others [14-17]. Jenny Morris [18] described independent living as:

...a means to an end: it is a way of people accessing their human and civil rights. Disabled people have the same human and civil rights as non-disabled people but we are different from non-disabled people in that we have additional requirements, such as mobility needs, communication assistance, personal assistance, and so on ([18], p. 428).

Independent living organizations (ILOs) have advocated for the goals and principles of the movement to be implemented in law and policy. ILOs are a distinct kind of disabled people's organization that focus on independent living, choice and control over services and participation in society. They are established primarily by disabled people, with a few exceptions of organizations that were founded by parents on behalf of their disabled sons or daughters. ILOs offer peer support, peer counseling and developed user-led services. Many ILOs have formed non-profit personal assistance user co-operatives which offer management and administration services in exchange for a small portion of the personal assistance payment.

Article 19 of the CRPD is a landmark for the international network of independent living organizations, which have struggled to have personal assistance recognized as a human rights issue. These organizations have been at the forefront of developing personal assistance services since the 1960s. Many of the key goals of independent living organizations are reflected in the general principles of the Convention, outlined in Article 3, which include freedom to make one's own choices, independence of persons, full and effective participation in society and equality of opportunity. The international disability community had a great deal of influence on the drafting of the CRPD as is reflected in the fact that there were 400 representatives of NGOs and disabled people's organizations 
in the drafting committee [19]. The important role of civil society continues to be recognized in the Convention itself, which requires that "persons with disabilities should have the opportunity to be actively involved in decision-making processes about policies and programs, including those directly concerning them" (preamble o). Under the heading "National implementation and monitoring", Article 33.3 of the Convention recognises that "civil society, in particular persons with disabilities and their representative organisations, shall be involved and participate fully in the monitoring process". Furthermore, Article 4.3 requires that:

In the development and implementation of legislation and policies to implement the present Convention, and in other decision-making processes concerning issues relating to persons with disabilities, states parties shall closely consult with and actively involve persons with disabilities, including children with disabilities, through their representative organisations [20].

Personal assistance is a cornerstone of the independent living movement. It is a catalyst for participation in society for persons who require a significant amount of support in their daily lives. The Convention does not contain a specific definition of "personal assistance". However, high level human rights organizations reflect definitions that were developed by the independent living movement. For example, a thematic study of independent living by the Council of Europe Commissioner for Human Rights [4] acknowledges that "persons with disabilities must have control over the support provided and be the ones who hire, employ, supervise, evaluate and dismiss their assistants". This reflects an earlier definition by Adolf Ratzka, a leader of both the Swedish and the European independent living movements. He explained that

"Personal" assistance means that users exercise the maximum control over how services are organised and custom-design their services according to their individual needs, capabilities, life circumstances and aspirations. In particular, personal assistance requires that the individual user decides: who is to work, with which tasks, at which times, where and how. Thus, the individual user must be able to recruit, train, schedule, supervise, and, if necessary, fire his or her own assistants. Simply put, "personal assistance", means that the user is the boss [17].

These definitions emphasize the control that users should have over their personal assistance scheme. There is an emphasis on user-leadership. However, in his definition of personal assistance, Adolf Ratzka also acknowledges that "users with learning or mental disabilities will need support from third persons with these functions" [17].

\section{Independent Living and Personal Assistance in Sweden}

Independent living organizations were the strongest advocates for the implementation of personal assistance law and policy in Sweden. The first Scandinavian conference on Independent Living was held in Stockholm in 1984 and was organized by Adolf Ratzka alongside leaders from the movement in the United States [17]. The Stockholm Centre for Independent Living (STIL) was established that same year. STIL comprised a non-profit user co-operative and offered peer support to members on how to become employers of personal assistants. The Gothenburg co-operative for independent living was founded in 1989. Other centers for independent living emerged in the early 1990s. In most countries, ILOs were developed primarily by and for persons with physical impairments [13]. However, in Sweden, ILOs diversified to reflect the heterogeneity of persons who wanted to access to personal assistance services. For example, the JAG association was established in 1992 , followed by a non-profit user co-operative in 1994. The JAG organization pioneered a model of personal assistance $^{2}$ for individuals who require support from a third party to co-ordinate the scheme 
on their behalf. The model is based on the premise that all people, regardless of impairment can self-determine if they have the appropriate individual support [21]. Non-profit user co-operatives spread throughout Sweden in the 1990s. In 1993, the Gothenburg Independent living co-operative and STIL established the Institute on Independent Living (ILI) which has "trained over 600 persons on how to manage the transition from being object of the local government's home help services to becoming good employers of their personal assistants and how to start up similar cooperatives" [22].

Swedish personal assistance providers are not limited to user co-operatives. In fact, user co-operatives only accounted for $9.2 \%$ of personal assistance providers in 2015, while for-profit companies were $54 \%$ of providers [7]. This is a result of calls for a market-driven approach to personal assistance, whereby individuals receive direct payments instead of services from the state and have a choice between a range of for-profit and non-profit providers $[23,24]$. This approach appealed to the center-right coalition government that was in power between 1991 and 1994. There was an increase in private providers during the 1990s in areas such as health care, primary school education and social services [24]. This continued after the election of another center-right coalition in 2006. The Act on System of Choice in the Public Sector [25] applies to health and social services (excluding services for children). The Act strengthens a "system of choice" in welfare, which "means a procedure where the individual is entitled to choose the supplier to perform the service and with which a contracting authority has approved and concluded a contract" (Article 1). The market of private providers was one of the most contentious issues when developing and implementing a law for personal assistance. There was significant political opposition against the private market using public funds to provide services [23]. This tension persists. For example, a report entitled "Measures to Combat Fraud and Misconduct with Assistance Allowance" [26] argued that there are strong economic incentives for companies to increase the number of hours for their customers in order to maximize profits.

Due to the fast growing numbers of personal assistance users, there have been increased attempts to regulate the market for personal assistance providers. The year 2009 was the first time personal assistance providers, including user- co-operatives had to apply for authorization to offer services. In 2015, 1109 assistance providing agencies were registered with the Health and Social Care Inspectorate (Inspektionen för vård och omsorg (IVO)) [7,27]. While many of these companies claim to abide by independent living principles, they are not necessarily led by disabled persons or their family members. Therefore, when we refer to ILOs, we are specifying those that are run primarily by disabled people and those that are run by relatives on behalf on their disabled family member. It was these ILOs that were instrumental in the development of personal assistance law and policy.

\subsection{Swedish Personal Assistance Law and Policy}

Personal assistance is one of ten rights outlined in the Act Concerning Support and Service for Persons with Certain Functional Impairments [28]. Other rights covered in the legislation include, relief service in the home, short-term respite stays, specially serviced housing for adults or other specially adapted housing for adults and daily activities for people of working age who are not employed in the open labor market [6]. The goals of LSS include "equality in living conditions", "full participation in the life of the community", "to live as others do" and "self-determination and privacy". Personal assistance applies to persons with "major and lasting functional impairments" who require assistance with five "basic needs": (1) personal hygiene; (2) meals; (3) dressing and undressing; (4) communication with others; and (5) help that requires extensive knowledge about the person with a functional impairment [28]. If a person qualifies for personal assistance, the number of hours of assistance per week should be calculated based on how much assistance they require due to these five needs.

The majority of personal assistance is funded and administered at national level. Askheim et al. ([29], p. 14) point out that personal assistance was implemented in Sweden in the early 1990s during a recession and therefore the "handing over of the main financial responsibility to the state could...be seen as a strategy for 'protecting' vulnerable groups against financial cutbacks 
in municipalities". An applicant for personal assistance must be assessed as requiring more than $20 \mathrm{~h}$ per week in order to qualify for state-funded personal assistance at the Social Insurance Agency (Försäkringskassan). If an applicant is assessed as needing less than $20 \mathrm{~h}$ they can apply for municipal personal assistance. People who have personal assistance are supposed to be reassessed every two years. Hence, people may have to move from the national to the municipal system upon reassessment of their needs if they fall below the $20 \mathrm{~h}$ threshold required for receiving state-funded assistance. People who lost state-funded personal assistance due to reassessment, received, on average a $25 \%$ reduction in their hours (from 72 to $54 \mathrm{~h}$ per week) when they transferred from state to municipal system [30]. This is problematic because there is a difference between national and local government policies and municipal policies vary. This problem was identified by the UN Committee on the Rights of Persons with Disabilities ([31], p. 2), which noted in their general comment to the Swedish government that "there is a serious gap between the policies followed by the state party and those followed by the municipalities with respect to the implementation of the Convention".

\subsection{Civil Society's Influence on Law and Policy}

Swedish personal assistance illustrates how the demands of ILOs are articulated in law and policy. The legislation is the "envy of many representatives of the international independent living movement" ([6], p. 2). There is a deeply rooted tradition of popular movements in Sweden that put pressure on pressure on the government and they are important consultative partners, showing how services are arranged in practice [32]. There were several ways in which Swedish independent living organizations influenced law and policy. For example, members of ILOs took part in a personal assistance pilot project in six local governments throughout Stockholm in 1987 [22]. They led the way in demonstrating the viability and desirability of personal assistance as an alternative to traditional, segregated services [8]. Members of the movement lobbied and met with politicians and succeed in finding political allies in government. There was a breakthrough when a close political allie of the independent living movement became the Deputy Prime Minister of Sweden in 1991. In 2012, Adolf Ratzka [23] wrote that "in retrospect, the reform, which added to the state budget what were once municipal expenditures, must be viewed as the result of Bengt Westerberg's strong personal commitment to the issue". Furthermore, members of the Swedish independent living movement were successful in their calls for national-level funding of personal assistance. Disabled people argued that "to be able to live in any municipality with the same quality of life...the responsibility for financing must be as centralized as possible" [33].

Sweden was not the only European country to implement personal assistance law and policy. However, it had the most extensive provisions in terms of who was entitled. This is due to the strong advocacy and pressure from independent living organizations. For instance, members of the JAG association met with politicians and ran an intense campaign to include persons who could not direct personal assistance for themselves to be included in the legislation [34]. As a result, personal assistance is available to children and adults with intellectual and physical disabilities, autism and acquired brain injuries.

While many principles of the independent living movement were reflected in the goals of the Swedish legislation, some issues divided the independent living movement and the government. Consumer choice of personal assistance providers, including private companies was one of the more controversial issues in the lead up to the law and policy reform. Sections of the independent living movement campaigned for direct payments instead of services, and for a wide choice of personal assistance providers. They faced opposition from, for instance, the municipal workers union and the communist party [23]. On the other hand, consumer choice appealed to the center right coalition government that was in power between 1991 and 1994, when personal assistance law and policy was developed and implemented. Calls for direct payments and consumer choice between many for-profit and non-profit providers prevailed and resulted in an unregulated market of personal assistance providers until 2009. 


\subsection{Justifications for Law and Policy Reviews}

The goals of the Swedish law and policy for personal assistance demonstrate a social understanding of disability and bear a striking resemblance to some of the general principles of the Convention [35]. How can it be that the government is reviewing personal assistance law and policy with the aim to restrict access to this service immediately following the ratification of the CRPD which clearly strengthens access to personal assistance?

Our analysis indicates that a major reason for the reviews was due to an unprecedented rise in demand for personal assistance, which far exceeded the government's initial expectations when the law was implemented. In 1994, it was estimated that 7000 people would receive assistance, for an average of $40 \mathrm{~h}$ per week. In 2014, more than 16,000 persons received assistance, for an average of $126 \mathrm{~h}$ per week [36]. The crucial difference between personal assistance and other services is that it is demand-driven [23]. Furthermore, there was no limit on the amount of money the government would allocate towards the personal assistance budget. Hence, the cost of personal assistance grew beyond expectations.

Concerns arose that a significant proportion of personal assistance payments were not being used for what the legislation intended. A report, published in 2012 entitled "Measures to Combat Fraud and Misconduct with Assistance Allowance" produced by an Inquiry on State Assistance argued that a significant proportion of state funds for personal assistance are a result of over-use, fraud or cheating during the assessment process [26]. The report suggested that these problems were a result of the strong economic incentive to seek the maximum number of hours and the weak monitoring and controls in place at the Social Insurance Agency. Furthermore, there were concerns about municipalities overusing state-funded personal assistance. Some reports have suggested that municipalities grant too many hours of personal assistance, thereby passing the costs on to the state instead of providing municipal services, which they would have to pay for if the person needed less than 20 hours of assistance per week $[26,36]$.

The government claims that a stricter definition of "basic needs" is required for clearer rules and guidelines to increase safety, uniformity and consistency of the assessment process [12]. It justified a review of the original goals of the legislation, claiming that they were too ambiguous. For instance, the Social Insurance Inspectorate (Inspektionen för socialförsäkringen) ([36], p. 4) suggested that key concepts underpinning the legislation, such as participation and independence were not defined in the law or legislative history. Another area of concern is the potential for personal assistance providers, in particular, for-profit companies, to misuse the direct payment system to make large profits from state funds.

\subsection{Reinterpreting "Basic Needs"}

Since the government ratified the Convention in 2008, several measures have been taken to clarify what it means to "need" personal assistance. The five "basic needs" outlined in the LSS have undergone intense scrutiny. Prior to this review process, civil society organizations representing disabled people collaborated with the government and influenced the policy making process. Disabled people's organizations and ILOs in particular, were instrumental in the original development of personal assistance law and policy. However, the relationship between the government and civil society organizations deteriorated during policy and legal reviews. In 2010, the National Board of Health and Welfare reported that representatives from the disability movement withdrew from a reference group in protest to proposals for a new assessment process, claiming that, among other things, it was too intrusive [37]. As a result, ILOs and other disabled people's organizations are on the margins or excluded from the policy review process. Instead of the previous collaborative process of policy making, the courts have become the main authorities in the review of "basic needs" for personal assistance. Interpretations of the courts were regarded as problematic by the UN Committee on the Rights of Persons with Disabilities ([31], p. 2). In their concluding observations to Sweden, the Committee said it was: 
...concerned that the Convention has not been integrated into Swedish law and is therefore left to the interpretation of authorities and courts. The Convention articles cannot serve as guidelines in court rulings, as they are not explicitly included in the texts of the national law [31].

The Social Insurance Agency was authorized by the government to develop tools and methods that would lead to a more consistent and fair assessment process [38]. The Agency did so by closely scrutinizing the interpretation of "basic needs" in court rulings. In 2011, a report by the Social Insurance Agency aimed to determine what does and what does not constitute a "basic need" for personal assistance. It did so by reviewing thirty-five judgments that were made by administrative and county courts between July 2009 and September 2010 [12]. In all of these cases, only three of five "basic needs" were considered by the courts: dressing and undressing, meals, and personal hygiene. The other two needs, assistance with communication and help that requires extensive knowledge about the person, were not considered in any of the rulings. In the majority of these rulings, judges reference an earlier ruling by the Supreme Administrative Court ${ }^{3}$ [12] in 2009. The court ruled that only needs that are considered to be of a very private nature, of a demanding and complex nature and of very personal character ([12], p. 8) were necessary to qualify for personal assistance. For instance, the need to prepare and pick up food with a knife and fork was not of a sensitive nature and therefore should not be considered the assessment of "basic needs" ([12], p. 8).

The court cases referenced in the report went into detail about the nature of the person's impairments and the support they required. Some of the "basic needs" judged to qualify an individual for personal assistance were: assistance to wipe oneself after using the toilet ${ }^{4}$ and the need for constant supervision during meals, difficulty chewing and swallowing and a tendency to vomit ${ }^{5}$. The report described one particular case involving a woman who was described as having weakness and numbness on one side of her body and a visual impairment as a result of a stroke. Only three of the five "basic needs" were considered in the case. In relation to the first need, help with dressing and undressing, it was noted that she could not put on her bra, pull up her pants and required assistance with zippers, buttons on jackets and with her shoes. The second need, meals, it was stated that she could not make a sandwich, peel potatoes, gut fish, or pour a milk carton. The third need, personal hygiene, it was noted that she depended on assistance to transfer to the toilet and to the shower chair and that it took a very long time for her to wash the "healthy" side of her body. The court ruled that she did not satisfy the "basic needs" for personal assistance. It was suggested that her needs could be met by the social welfare committee and by her husband ([12], p. 27).

\subsection{Medicalisation of Needs}

The shift from a medical, towards a social understanding of disability is a key element of the CRPD. The recent reviews of Swedish personal assistance law and policy have focused on defining who is eligible based on impairment and medical classification. In its ruling on 25 June 2015, the Supreme Administrative Court concluded that the fifth "basic need" (assistance from another person who has detailed knowledge of the user) only applies to persons "with mental disabilities". Following this ruling, a report by the Social Insurance Agency [39] noted that there was no uniform definition of mental disability, and this, therefore, would have to be clarified. In December 2015, the Social Insurance Agency published a report [40] defining mental disability as reduced mental function. Their definition drew on the World Health Organisation's International Classification of Functioning, Disability and Health (ICF). If a person claims that they need assistance from another person who has detailed knowledge of the user, they must first prove that they have a mental disability by producing a

\footnotetext{
The ruling by the Supreme Administrative Court is referenced in the report as "RA 2009 ref. 57".

Appeal in Sundsvall (Case No. 3845-08).

Appeal in Jönköping (Case No. 48-10).
} 
medical certificate. Although the implications of this ruling remain to be seen, the Social Insurance Agency [39] has acknowledged that persons who do not meet their definition of mental disability will lose assistance upon reassessment of their "basic needs". This example demonstrates a shift to a medical understanding of the need for personal assistance. In 2015, the Social Insurance Inspectorate was commissioned by the government to produce a report "to provide an analysis and define shortcomings in legislation and its application" [36]. The report by the Social Insurance Inspectorate suggests that:

...one way to make the assessment more transparent would be to start from the International Classification of Functioning, Disability and Health (ICF) and convert the assessment based on ICF to the number of hours that would be reasonable to grant to the person. Also, regulations about which medical professions that should be allowed to issue medical certificates regarding functional ability need to be considered ([36], p. 5).

The Government's strategy for the Social Insurance Agency in 2016 outlines its goals for personal assistance benefits. The government instructs the Agency to help break the trend of the hours for assistance benefit by ensuring uniform application of the law, combating overuse and to promote medical investigations and to ensure that the medical investigation is of high quality [41].

\subsection{Civil Society, the CRPD and the Cutbacks}

The cutbacks are continuing despite concerns from the UN Committee on the Rights of Persons with Disabilities report in 2014 [31]. In its concluding observations to Sweden, it made the following comment:

The Committee is concerned that state-funded personal assistance has been withdrawn for a number of people since 2010 due to a revised interpretation of "basic needs" and "other personal needs", and that persons who still receive assistance have experienced sharp cutbacks, the reasons for which are unknown or only seemingly justified ([31], p. 6).

This raises the question of why the CRPD has not prevented the deterioration of personal assistance law and policy in Sweden. The qualitative research carried out for the wider project, conducted in Sweden in 2013, we found very little evidence that the CRPD was being used by ILOs in the years following ratification. Some leaders of independent living organizations complained that all of their energy was spent on challenging and opposing further deterioration of the law, resulting in insufficient time to develop strategies to advance the CRPD in Sweden. Recently, however, there is evidence to suggest that the CRPD is being used by ILOs as a tool to fight the revised interpretations of law and policy. One example is an organization called "Med lagen som verktyg" (MLSV) ("With the Law as a Tool" in English). The organization was established in 2015. It aims to defend and advance human rights for people with disabilities and counter disability-based discrimination in Sweden [42]. This is the first collective effort by the Swedish independent living movement to challenge the deterioration of the law and policy by using the CRPD. Another example is the Independent Living Institutes (ILI) development of a website which features an online service for reporting disability based discrimination and provides a database with information about personal assistance service providers in Sweden [42]. This is an example of capacity building and dissemination of information regarding the policy changes. Articles and papers on the website highlight the value of personal assistance, which is strikingly different to the focus of the government reports. These examples reflect the resistance against the policy reviews and the current conflict between the independent living movement and the government. This is in contrast to the previous collaboration in the policy process and is far from the requirements of the CRPD to include disabled people and their organizations in policies and practices influencing their lives.

\section{Discussion}

Changes to Swedish personal assistance law and policy demonstrate the precariousness and fragility of rights. People who have had personal assistance for several years, now risk losing it, not 
because their needs or their impairments have changed, but because of new interpretations of the law and new administrative approaches to assessing needs.

At the beginning of this paper, we asked if Sweden is violating its commitments under the Convention. The Council of Europe's Commissioner for Human Rights [4] Thomas Hammarberg, who is Swedish, wrote an issue paper on the implementation of Article 19. In it, he highlighted the importance of collecting historical data in order to measure trends over time, including progression or regression. Measuring an "increase or decrease in types and size of entitlements, and...the number of beneficiaries of support services in the community" over time is one of the indicators for monitoring the extent to which Article 19 of the CRPD is violated ([4], p. 52). Extensive statistical information and data have been available in Sweden since personal assistance was outlined in legislation in 1993. Hence, an abundance of statistics, historical documentation and policy papers documenting the Swedish experience of personal assistance provide valuable information on progress or regression over time. In this final section, we discuss changes in personal assistance law and policy and consider if Sweden is in breach of its obligations under the CRPD.

\subsection{From a Social to a Medical Understanding of Disability}

The goals of the Swedish law for personal assistance bear a striking resemblance to some of the general principles of the CRPD including full and effective participation in society and equality of opportunity. Likewise, the goals of LSS include "equality in living conditions", "full participation in the life of the community", "to live as others do" and "self-determination and privacy" [28]. These goals reflect the influence of independent living organizations in the formulation and implementation of personal assistance law and policy. ILOs collaborated actively in developing a social, rights-based understanding of personal assistance by emphasizing its value for individual users, their family members and the wider society. However, when civil society organizations withdrew from a reference group working on the policy reviews the Social Insurance Agency and the courts became the main authorities when interpreting "basic needs" for personal assistance [37]. Major policy decisions, which ultimately lead to cutbacks, were made in the absence of key representatives from DPOs. We would argue that this compromises Sweden's obligation to involve disabled people and their representative organizations in decision making processes relating to law and policy for personal assistance.

Court rulings and reviews of eligibility criteria have shifted from the original goals of the law towards a medical understanding of disability, which focuses on deficit rather than equality and participation in society. The Social Insurance Agency used the World Health Organisation's International Classification of Functioning, Disability and Health (ICF) to define mental disability as reduced mental function [40]. This is a limited and selective interpretation of the ICF, which addresses four areas: (1) bodily functions; (2) bodily structures; (3) activity and participation; and (4) environmental factors [43]. The Swedish Social Insurance Agency has focused mainly on the first two areas and appears to have much less emphasis on the second two, despite the fact that they are clearly more in line with the CRPD's understanding of disability. This selective use of the ICF does not take its broader frame into consideration when applying it to measure entitlements to personal assistance. In this context it is also noteworthy that General comment (number 5) by the UN Committee on Economic, Social and Cultural Rights (ESCR) outlines "the right to physical and mental health also implies the right to have access to, and to benefit from, those medical and social services-including orthopedic devices - which enable persons with disabilities to become independent, prevent further disabilities and support their social integration" [44]. Whichever measurements are used to allocate personal assistance, the aim should be to enhance the applicant's independence and social participation. However, currently, it appears that in Sweden measurements are employed to restrict and limit access to personal assistance based on narrow medical considerations and this is a clear sign of regression in implementing Article 19. 


\subsection{Confrontation in Courts}

This paper has highlighted the shift from a collaborative approach to policy making, towards a confrontational reaction to the policy reviews. Instead of collaboration, the courts have become the main authority when interpreting the law and have emerged as a battleground for determining rights. This is particularly problematic considering that the UN Committee on the Rights of Persons with Disability ([31], p. 2) highlighted that the Convention "has not been integrated into Swedish law and is therefore left to the interpretation of authorities and courts". If the struggle for personal assistance is moved to the courts, then it is of utmost importance that judges and lawyers are well-informed about the CRPD and the social understanding of disability.

The court rulings and the subsequent reports by the Social Insurance Agency reveal the high levels of surveillance and scrutiny an individual is subjected to when she or he challenges the assessment of their "basic need" for personal assistance. The 2011 report by the Social Insurance Agency which assessed the court rulings, provided details about the age, gender, the municipality in which the person resided and when into detail about the nature of their impairment. Ironically, privacy is one of the goals of the legislation [28]. As a result, Sweden may be in violation of its obligation under Article 22 of the CRPD, which requires that states "shall protect the privacy of personal, health and rehabilitation information of persons with disabilities on an equal basis with others".

\subsection{Over-Use or High Demand?}

In many ways, personal assistance policy is a victim of its own success. A tension has arisen whereby, on one hand, the disabled people's movement sees the increase in personal assistance as a success because more and more people are able to live in the community, lead independent lives and participate in society. The government, on the other hand, views the unexpected increase and rising costs of personal assistance as out of control and a sign of fraud or over-use. Personal assistance is different from other services because it is demand-driven, rather than supply-driven [23]. The independent living movement has measured its success in relation to the desirability and demand for personal assistance. Its success was reflected in the diverse groups that joined the campaign to have access to personal assistance services.

The principles of choice, control and individual autonomy that underpin personal assistance appealed to the center-right coalition government that was in power in the early 1990s [23]. Personal assistance has also been presented as a cost-saving service because of the minimal role of the state in administrating services and employing staff. This cost saving, however, was largely dependent on people transitioning from a costly state service, such as residential care, to personal assistance and did not take into consideration persons who were living with their families, receiving unpaid, informal care from family members, relatives and others. The demand for personal assistance far exceeded the government's initial expectations when the law came into force in 1994. Government reports portray personal assistance law and policy as a problem in need of fixing, without considering the societal and individual value. Even the titles of reports make personal assistance sound like a problem; for instance, the report entitled "Assistance Benefit-Shortcomings in Legislation and Application" [36]. The Swedish government sees the increase as the consequence of overuse, both in numbers of individual users and hours that the individual personal assistance user is allowed. As a result, the eligibility criterion for accessing personal assistance has become a matter of public debate and intense bureaucratic scrutiny.

\subsection{Targeting Individuals rather than for-Profit Providers}

The state has legitimate concerns regarding the regulation of the market of assistance providers. Some effort has been made to weed out rogue companies. Cases of fraud and overuse of personal assistance payments has strengthened the government's argument for regulation of personal assistance providing agencies. However, most of the cutbacks have been directed at individuals, rather than 
the service providers. Private providers continue to profit from state funds, while there is a sharp rise in the numbers of persons losing their state-funded personal assistance. The distinction between for-profit personal assistance providers and non-profit co-operatives that are part of ILOs run by and for disabled people or their relatives is important when discussing state obligations under the CRPD. It was the ILOs and user co-operatives that pioneered personal assistance services in Sweden. It is these ILOs that developed the independent living movement and independent living principles in Sweden. Hence, they are particularly well positioned to guide the policy making process and monitor the implementation of Article 19.

\section{Conclusions}

In countries that already have incorporated personal assistance into law and policy, such as Sweden, the CRPD should have strengthened this service. Sweden has been at the forefront of advocating for and developing wide ranging rights to personal assistance in Europe since the 1980s and has served as an inspiration to other countries. Due to this, in our study of the implementation of Article 19 in three Nordic countries, we assumed that Sweden would be the "star" country. Instead we found that since Sweden ratified the CRPD in 2008 many disabled people have lost their personal assistance at a state-level or had their first application rejected.

This situation is disturbing to those advocating for human rights under the CRPD and can be an important lesson for other countries. Sweden is not the only European country to exercise cutbacks to personal assistance and services that support independent living. Other examples are found in the UK and the Netherlands [45]. As a result, some disability activists and disability scholars are cautious about the positive impact that the CRPD will have in practice $[3,46]$. There are concerns that the CRPD came into force shortly before a recession and austerity measures in Europe, which threatened the future and the sustainability of independent living and personal assistance in countries that implemented relatively extensive policies prior to the Convention. Clearly, states have the right to take regressive measures if there are "strong justifications" for doing so ([47], p. 16). While it could be argued that the unprecedented cost is a strong justification, in the case of Sweden, it is noteworthy that personal assistance law and policy were introduced during a recession in the 1990s [29]. Another interesting point is that the Swedish economy was less affected than other European countries in the recession that began after 2008. Furthermore, a contradiction arises whereby companies profiteer from personal assistance provision, while, at the same time, measures are taken to control costs by reinterpreting basic needs of individual users.

How can it be that a country with extensive legal rights to personal assistance prior to ratifying the CRPD has, upon ratification, cut back rights that are clearly articulated in the Convention? We have attempted to answer this question in this paper. Regressive action is not prohibited under international law which begs the question if these cut backs are justifiable under the limited principles that governing regression. Our conclusion is that the reinterpretation of the criteria for accessing personal assistance constitutes regression beyond what can be justified and, thus, violates the progressive achievement called for in the CRPD. As a result, we conclude that Sweden is in violation its obligations under the CRPD.

Acknowledgments: This work was supported by the FP7 Marie Curie Initial Training Network (ITN) DREAM, Disability Rights Expanding Accessible Markets (DREAM). Project ID: 265057. 
Author Contributions: Ciara Brennan and Rannveig Traustadóttir conceived and designed the overall research with input from Peter Anderberg and James Rice. All four authors took part in conceptualising the article. Ciara Brennan was an Early Stage Researcher (ESR) for a Marie Curie Training Network entitled Disability Rights Expanding Accessible Markets (DREAM) and is a Ph.D. candidate at the University of Iceland. This article is a part of her PhD dissertation. She conducted the qualitative fieldwork in Iceland, Norway and Sweden and the data analysis under the supervision and advice of the co-authors. Ciara Brennan also carried out the policy analysis and literature review and took the main responsibility for the writing. During the writing process her co-authors read and commented on drafts of the paper. Rannveig Traustadóttir took active part in advising during the writing process and contributed to the writing of parts of the article. Peter Anderberg provided key materials and data, and his expert knowledge on Swedish personal assistance and independent living that facilitated data collection, analysis and writing. James Rice took part in conceptualising the article and read and commented on drafts during the writing process.

Conflicts of Interest: The authors declare no conflict of interest.

\section{References and Notes}

1. Office of the High Commissioner for Human Rights. "Priority issues and recommendations for the high-level meeting of the general assembly on disability and development and its outcome document: Inclusion of the rights of persons with disabilities in the post-2015 agenda." 2013. Available online: http://goo.gl/Id4ZOx (accessed on 12 December 2015).

2. Gerard Quinn, and Suzanne Doyle. Getting a Life. Living Independent and Being Included in the Community. Legal Analysis of the Current Use of Structural Funds to Contribute to the Achievement of Article 19 of the UN Convention on the Rights of Persons with Disabilities. Geneva: Office of the United Nations Commissioner for Human Rights Regional Office for Europe, 2012.

3. Rosemary Kayess, and Phillip French. “Out of darkness into light? Introducing the convention on the rights of persons with disabilities." Oxford Journals Human Rights Law Review 8 (2008): 1-34. [CrossRef]

4. Council of Europe Commissioner for Human Rights. "The right of people with disabilities to live independently in the community." 2012. Available online: https://wcd.coe.int/ViewDoc.jsp?id=1917847 (accessed on 10 January 2014).

5. United Nations Office of the High Commissioner for Human Rights. Economic, Social and Cultural Rights: Handbook for National Human Rights Institutions. Geneva: United Nations, 2005.

6. Peter Anderberg. "Aned country report on the implementation of policies supporting independent living for disabled people." 2009. Available online: http://www.disability-europe.net/content/aned/media/SE6-Request-07\%20ANED\%20Task\%205\%20Independent\%20Living\%20Report\%20Sweden_to\%20publish_ to\%20EC.pdf (accessed on 5 April 2014).

7. Assistanskoll. "Statistics on personal assistance [statistik om personlig assistans]." 2015. Available online: http:/ / assistanskoll.se/assistans-statistik.php (accessed on 16 December 2015).

8. Ciara Brennan. "Article 19 and the nordic experience of independent living and personal assistance." In $A$ Research Companion to Disability Law. Edited by Peter Blanck, Eilionoir Flynn and Gerard Quinn. Farnham: Ashgate, 2016.

9. Ciara Brennan, Rannveig Traustadóttir, Peter Anderberg, and James Rice. “Negotiating independence, choice and autonomy: Experiences of parents who co-ordinate personal assistance on behalf of their adult son or daughter." Disability and Society, 2016, forthcoming.

10. Kathy Charmaz. Constructing Grounded Theory. London: Sage, 2006.

11. John W. Creswell. "Qualitative inquiry and research design." In Choosing among Five Approaches, 2nd ed. Thousand Oaks: Sage, 2007.

12. Social Insurance Agency. Decisions Overview_Personal Assistance [Rättsfallsöversikt_Personlig Assistans]. Stockholm: Social Insurance Agency, 2011.

13. Gerben DeJong. "Defining and implementing the independent living concept. Developing, implementing, and evaluating self-help rehabilitation programs." In Independent Living for Physically Disabled People. Edited by Nancy Crewe and Irving Zola. New York: Jossey Bass, 1983.

14. Simon Brisenden. "Independent living and the medical model of disability." Disability, Handicap and Society 1 (1986): 173-78. [CrossRef]

15. Jenny Morris. “Community care or independent living? " Critical Social Policy 14 (1994): 24-45. [CrossRef]

16. John Glasby, and Rosemary Littlechild. Social Work and Direct Payments. Bristol: The Policy Press, 2010. 
17. Adolf Ratzka. "Introduction to direct payments for personal assistance." 1996. Available online: http: / /www.independentliving.org/docs4/directpay.html (accessed on 18 March 2013).

18. Jenny Morris. "Independnet living and community care: A disempowering framework." Disability and Society 19 (2004): 427-42. [CrossRef]

19. Arlene S. Kanter. "The law: What's disability studies got to do with it or an introduction to disability legal studies." Columbia Human Rights Law Review 42 (2011): 403-79.

20. United Nations. "Convention on the Rights of Persons with Disabilities. Article 4.3." 2007. Available online: http://www.un.org/disabilities/convention/conventionfull.shtml (accessed on 11 January 2013).

21. JAG. The Price of Freedom of Choice, Self-Determination and Integrity. A Cost Analysis of Different forms of Support and Service to People with Extensive Functional Impairments. Stockholm: JAG, 2006.

22. Adolf Ratzka. "STIL, the stockholm co-operative for independent living." 1996. Available online: http: / /www.independentliving.org/docs3/stileng.html (accessed on 13 March 2016).

23. Adolf Ratzka. "The independent living movement paved the way: Origins of personal assistance in Sweden." 2012. Available online: http://www.independentliving.org/docs7/Independent-Living-movement-pavedway.html (accessed on 6 February 2016).

24. Paula Blomqvist. "The choice revolution: Privatization of swedish welfare services in the 1990s." Social Policy and Administration 38 (2004): 139-55. [CrossRef]

25. "The Act on System of Choice in the Public Sector." Reference number 2008: 962. Available online: http: / /goo.gl/OfXjv0 (accessed on 10 May 2016).

26. Inquiry on Assistance Compensation Costs. "Åtgärder mot fusk och felaktigheter med assistansersättning (Measures to combat fraud and misconduct with assistance allowance)." 2012. Available online: http: / / regeringen.se/content/1/c6/18/63/04/7bc4f4f9.pdf (accessed on 14 January 2015).

27. Health and Social Care Inspectorate. "Personal assistance [personlig assistans]." 2015. Available online: http:/ /www.ivo.se/tillstand-och-register/lss-tillstand/personlig-assistans/ (accessed on 30 January 2016).

28. The Swedish Act concerning Support and Service for Persons with Certain Functional Impairments (LSS), Reference number 1993:387 [Lag om stöd och service till vissa funktionshindrade]Lag (1993:387)

29. Ole Petter Askheim, Hans Bengtsson, and Bjarne Richter Bjelke. "Personal assistance in a scandinavian context: Similarities, differences and developmental traits." Scandinavian Journal of Disability Research 16 (2014): 3-18. [CrossRef]

30. National Board of Health and Welfare. "Mapping and analysis of certain activities under lss [kartläggning och analys av vissa insatser enligt lss-Tilläggsuppdrag avseende insatsen personlig assistans]." 2015. Available online: http:/ / www.socialstyrelsen.se/publikationer2015/2015-9-3 (accessed on 18 January 2016).

31. Committee on the Rights of Persons with Disabilities. "Concluding observations on the initial report of Sweden crpd/c/swe/co/1." 2014. Available online: http://goo.gl/1xqFpi (accessed on 12 September 2015).

32. Ulla Clevnert, and Lennarth Johansson. "Personal assistance in sweden." Journal of Aging and Social Policy 19 (2007): 65-80. [CrossRef] [PubMed]

33. Adolf Ratzka. "Personal assistance and attendant care in sweden. A consumer perspective." 1996. Available online: http:/ /www.independentliving.org/docs1/ar1986spr.html (accessed on 3 January 2016).

34. JAG. The "Jag Model"-Persnoal Assistance with Self-Determination. Stockholm: JAG, 2011.

35. Rannveig Traustadóttir. "Disability studies, the social model and legal developments." In The United Nations Convention on the Rights of Persons with Disabilities. European and Scandavinian Perspetives. Edited by Gerard Quinn and Oddny Mjoll Anardóttir. Boston: Martinus Nijhoff, 2009.

36. Social Insurance Inspectorate. Assistance Allowance: Shortcomings in the Law and Application [Assistansersättningenbrister i Lagstiftning och Tillämpning]. Stockholm: Social Insurance Inspectorate, 2015.

37. National Board of Health and Welfare. "Assessment of need for personal assistance." 2010. Available online: http:/ / www.socialstyrelsen.se/nyheter/2010januaritillseptember/assistans (accessed on 22 January 2016).

38. Social Insurance Agency. Response to Government Mandate. Reply Regarding Assistance. Stockholm: Forsakringskassan, 2011.

39. Social Insurance Agency. "Questions and answers. Social insurance agency's interpretation of the judgment by the supreme administrative court concerning assistance [Frågor och svar försäkringskassans tolkning av dom från högsta förvaltningsdomstolen gällande assistansersättning]." 2015. Available online: https: / / goo.gl/8Hv747 (accessed on 23 January 2016). 
40. Social Insurance Agency. "Mental disability in the assessment of basic needs [psykisk funktionsnedsättning vid bedömning av grundläggande behov]." 2015. Available online: https://goo.gl/FI3ffm (accessed on 8 February 2016).

41. Government of Sweden [Regeringen]. “Government's appropriation for the financial year 2016, for the social insurance agency [regleringsbrev för budgetåret 2016 avseende försäkringskassan]." Available online: http: / / www.esv.se/Verktyg--stod/Statsliggaren/Regleringsbrev/?RBID=17015 (accessed on 12 February 2016).

42. Independent Living Institute. "Using the law as a tool-Project of the independent living institute (ili) med lagen som verktyg_Projektansökan av independent living institute (ili)." 2014. Available online: http:/ / www.independentliving.org/docs14/lagen-som-verktyg-projekt.html (accessed on 9 February 2016).

43. Jerome Bickenbach. "Monitoring the united nation's convention on the rights of persons with disabilities: Data and the international classification of functioning, disability and health." BMC Public Health 11 (2011): 1. Available online: http://www.ncbi.nlm.nih.gov/pmc/articles/PMC3104221/ (accessed on 20 December 2015). [CrossRef] [PubMed]

44. United Nations Enable. "Article 21-Right to health and rehabilitation." 2005. Available online: http: //www.un.org/esa/socdev/enable/rights/ahcstata21refjurisprudence.htm (accessed on 21 April 2016).

45. ANED. "Dotcom the online tool of the commission." Available online: http://www.disability-europe.net/ dotcom (accessed on 21 April 2016).

46. Michael Oliver, and Colin Barnes. The New Politics of Disablment. Leeds: Palgrave Macmillan, 2012.

47. Office of the United Nations High Commissioner for Human Rights. Frequently Asked Questions on Economic, Social and Cultural Rights. Geneva: Office of the United Nations High Commissioner for Human Rights, 2008.

(C) 2016 by the authors; licensee MDPI, Basel, Switzerland. This article is an open access article distributed under the terms and conditions of the Creative Commons Attribution (CC-BY) license (http:/ / creativecommons.org/licenses/by/4.0/). 